\title{
The district general hospital psychiatric unit and the mental hospital - some comparisons
}

\author{
PAUL WILLIAMS \\ Whitchurch Hospital, Whitchurch, Cardiff CF4 7XB
}

\begin{abstract}
SUMMARY
A new district general hospital psychiatric unit was opened at the University Hospital of Wales in June 1972. Information was obtained on all acute psychiatric hospital admissions in Cardiff for the year beginning 1 June 1972, and a comparison was made between patients admitted to the general hospital unit and those admitted to the menta hospital. The findings show that patients admitted to the general hospital unit tended to be younger, of higher social class, neurotic rather than psychotic, and to have had fewer previous admissions than patients admitted to the mental hospital. They will, however, probably stay in hospital longer. The implications of these trends are discussed.
\end{abstract}

\section{INTRODUCTION}

Late in 1971, the new 850-bed University Hospital of Wales was opened in Cardiff. The psychiatric unit of 48 beds was opened on 1 June 1972. It was felt that this provided an ideal opportunity to look at the types of patient admitted to psychiatric beds in Cardiff and to make some comparisons between the mental hospital and the new general hospital unit.

Accordingly, all patients admitted to an acute psychiatric bed during the first year after the opening of the new department were studied, and the results are presented below.

\section{Psychiatric Services in CaRdiff}

The City of Cardiff and its environs have a population of approximately 280,000 , and until June 1972 the adult psychiatric services were provided entirely by Whitchurch Hospital, with 600 beds. The hospital caters for all types of mental illness and houses an Academic Department of Psychological Medicine. Of the 600 beds, 155 are designated as admission beds: these are deployed in five wards, two male and two female under the care of National Health Service consultants, and one mixed ward run by the Academic Department of Psychological Medicine of the Welsh National School of Medicine.
The intensive care wards, designed for severely disturbed patients, and the Regional Centre for Drug Addiction and Alcoholism, although they accept acute admissions, do not come within the scope of this survey. The Day Hospital also is not included.

Admissions, as in most mental hospitals, are of two types. The 'arranged' admission in which the patient has been seen previously as an outpatient, on a domiciliary visit, etc., and is admitted to the ward of the consultant concerned; and the "emergency' admission. Emergencies are dealt with by the different clinical firms, depending on which day they arrive. Each consultant and his firm have one duty day per week, the academic unit counting for this purpose as one firm. All emergency referrals to the service are seen by the intaking registrar at the emergency assessment clinic, which is situated at Whitchurch Hospital, and a decision is made whether or not to admit the patient (usually after discussion with the consultant concerned).

The Department of Psychological Medicine at the University Hospital of Wales (UHW) was opened on 1 June 1972. The unit consists of 48 beds and 12 day places (not included in this survey). Thirty-two of the beds are allocated for academic department use, and the remaining 16, although under the administrative charge of the professor of psychiatry, for use by the NHS consultants. During the early part of the period under survey, only 10 of these non-academic beds were available owing to a serious shortage of nursing staff.

Admissions to the UHW unit occurred in the usual way, by referral from outpatient clinics and domiciliary visits, and as emergencies on the appropriate duty day via the emergency assessment clinic at Whitchurch Hospital.

\section{REASONS FOR THE STUDY}

As stated earlier, it was felt that the opening of a general hospital psychiatric unit provided an impetus for examination of the types of patient admitted to that unit and to the mental hospital, and for a comparison of the two groups. 
It had long been felt at Whitchurch Hospital that the admission beds were being 'silted up' with an elderly and chronic population. Although on paper the number of acute beds seemed adequate, only a small number were available for the turnover of acutely ill patients. As far back as 1967, an inpatient census (Brown, 1967, unpublished) found that only $23.5 \%$ of the inpatient population were likely to be discharged within six months.

At the time of the opening of the UHW unit, the policy stated by the professor of psychiatry was that there was to be no 'two-tier' service, no selection of 'better' patients for the UHW unit. It was felt that despite this policy directive and the efforts of all concerned to implement it there would inevitably be some evidence of the development of a two-tier service. This survey was designed principally to test this hypothesis.

\section{MethoD}

All patients admitted to an acute admission bed at Whitchurch Hospital (including the academic unit) and all patients admitted to the UHW unit between midnight on 31 May 1972 and midnight 31 May 1973 were included in the survey. A readmission was coded as a new admission, but several groups of patients were excluded from the survey:

(1) several patients transferred from the academic unit at Whitchurch Hospital to the UHW unit during the first few days of June. These had already been inpatients for some time;

(2) patients admitted to the alcoholism and drug addiction treatment centre at Whitchurch Hospital;

(3) patients admitted directly to the intensive care wards at Whitchurch Hospital. These patients, when they no longer require special care, are transferred to an admission ward under the care of the consultant who admitted them. It was reasonable to suppose that admissions of this nature were randomly distributed throughout the week and therefore would have no influence on the results.

Details of each patient were collected on a coding sheet. Personal details such as address, age, marital status, etc., were noted. Legal status on admission was also noted: if this changed during the patient's stay in hospital, this information was not included in the survey.

Occupation was classified according to the Registrar General's classification (General Register Office, 1971) into five social classes (social class III was subdivided into manual and non-manual). Single women under 21 years were classified according to the occupation of their father, and housewives according to the occupation of their husband. Unemployed persons were classified according to their most recent job when this information was available. Women over 60 years and men over 65 were designated as 'retired', and any patient about whom there was insufficient information or who for other reasons could not be assigned to a social class was designated as 'unclassified'.

The dates of admission and discharge were noted, and this information was coded as number of days' stay in hospital. If the stay was less than 24 hours, this was counted as one day. If the stay was longer than three months (90 days), this was counted as 'long stay'.

The route of admission, ward to which admitted, the number of previous admissions, mode of discharge, and disposal of the patient were obtained by inspection of the case notes.

Each patient was assigned to one of the diagnostic categories of the International Classification of Diseases (8th revision). This was done routinely by the registrar in charge of the patient, and the information was sent to the reception office at Whitchurch Hospital. As the registrars at the UHW unit were on secondment from Whitchurch Hospital, it was likely that diagnoses would be made according to the same criteria in both hospitals.

All the information was transferred onto Hollerith cards for analysis.

\section{RESULTS}

There were 48 available beds at UHW, which could be used for either sex. At Whitchurch Hospital there were 155 beds, 67 male and 88 female (male : female ratio $1: 1 \cdot 3$ ). During the period of the survey there were 223 admissions to the UHW unit, 68 male and 155 female, giving a male : female ratio of $1: 2 \cdot 3$ ), and 1,021 acute admissions to Whitchurch (388 male and 633 female, a male : female ratio of $1: 1 \cdot 63)$. During the year, therefore, each bed was occupied on average by 4.6 patients at UHW and by 6.6 patients at Whitchurch.

The acute admissions to Whitchurch Hospital were fewer than for the previous year, but this must be seen in the light of the decline in admissions to Whitchurch Hospital over the past five years. It is unlikely, therefore, that the opening of the UHW unit has lessened the demand on beds at Whitchurch Hospital. 


\section{Catchiment Area}

At the UHW unit $33(14 \cdot 8 \%)$ patients were from outside the catchment area. This compares with 81 $(7.9 \%)$ at Whitchurch. This may reflect the practice of referring cases of especial interest to the professorial unit (vide infra) or may be part of the "halo effect' which surrounds any new hospital.

\section{COMPULSORY ADMISSIONS}

Sixteen patients $(7 \cdot 2 \%)$ were admitted compulsorily to the UHW unit. Of the patients admitted to Whitchurch Hospital, $90(8 \cdot 8 \%)$ were under a compulsory order.

\section{AGE}

The mean age on admission to UHW was 29.6 years $(28 \cdot 2$ for male patients, 32.4 for female patients): the mean age of those admitted to Whitchurch was 46.7 years $(43.8$ for male patients and $49 \cdot 3$ for female patients). The distribution of ages is seen in Table I. Twelve UHW patients were over

TABLE I

AGE DISTRIBUTION OF PATIENTS

\begin{tabular}{|c|c|c|c|c|c|c|}
\hline \multicolumn{3}{|c|}{ Age (years) } & \multicolumn{2}{|c|}{$\begin{array}{c}\text { UHW } \\
\text { Admissions }\end{array}$} & \multicolumn{2}{|c|}{$\begin{array}{l}\text { Whitchurch } \\
\text { Admissions }\end{array}$} \\
\hline & & & No. & $\%$ & No. & $\%$ \\
\hline $\begin{array}{r}<20 \\
20-29 \\
30-39 \\
40-49 \\
50-59 \\
60-65 \\
>65\end{array}$ & $\begin{array}{l}\ldots \\
\cdots \\
\cdots \\
\cdots \\
\cdots\end{array}$ & $\begin{array}{l}\because \\
\because \\
\because \\
\because \\
\cdots\end{array}$ & $\begin{array}{l}29 \\
52 \\
43 \\
32 \\
43 \\
12 \\
12\end{array}$ & $\begin{array}{r}13 \cdot 0 \\
23 \cdot 3 \\
19 \cdot 3 \\
14 \cdot 3 \\
19 \cdot 3 \\
5 \cdot 4 \\
5 \cdot 4\end{array}$ & $\begin{array}{r}38 \\
204 \\
186 \\
177 \\
187 \\
93 \\
136\end{array}$ & $\begin{array}{r}3 \cdot 7 \\
20 \cdot 0 \\
18 \cdot 2 \\
17 \cdot 3 \\
18 \cdot 3 \\
9 \cdot 1 \\
13 \cdot 3\end{array}$ \\
\hline Total & .. & . & 223 & $100 \cdot 0$ & 1,021 & $100 \cdot 0$ \\
\hline \multicolumn{3}{|c|}{ Mean age } & \multicolumn{2}{|c|}{29.6 years } & \multicolumn{2}{|c|}{46.7 years } \\
\hline
\end{tabular}

65 years of age, nine women and three men. Of the 12,10 were suffering from depression, one from schizophrenia, and one from personality disorder. Of the 136 patients in this age group admitted to the admission wards of Whitchurch Hospital, 40 were male and 96 female. Of these, 46 suffered from depression, 36 from dementia, 11 from neurosis, and the remaining $\mathbf{4 3}$ from various other psychotic illnesses.

\section{Route of ADMission}

The routes of admissions of the two cohorts of patients can be seen in Table II. It can be seen that the UHW unit admits relatively few patients from the emergency clinic, and draws heavily on outpatient admissions. The implications of this finding will be discussed.
TABLE II

\begin{tabular}{|c|c|c|c|c|}
\hline \multirow[b]{2}{*}{ Route of Admission } & \multicolumn{2}{|c|}{$\begin{array}{l}\text { UHW } \\
\text { Admissions }\end{array}$} & \multicolumn{2}{|c|}{$\begin{array}{l}\text { Whitchurch } \\
\text { Admissions }\end{array}$} \\
\hline & No. & $\%$ & No. & $\%$ \\
\hline $\begin{array}{l}\text { Emergency clinic .. } \\
\text { Outpatients or } \\
\text { waiting list } \\
\text { Other hospital (non- } \\
\text { psychiatric bed) .. } \\
\text { Domiciliary visit . } \\
\text { Other .. }\end{array}$ & $\begin{array}{l}33 \\
89 \\
72 \\
18 \\
11\end{array}$ & $\begin{array}{r}14 \cdot 8 \\
39 \cdot 9 \\
32 \cdot 3 \\
8 \cdot 1 \\
4 \cdot 9\end{array}$ & $\begin{array}{r}481 \\
177 \\
186 \\
97 \\
80\end{array}$ & $\begin{array}{r}47 \cdot 1 \\
17 \cdot 3 \\
18 \cdot 2 \\
9 \cdot 5 \\
7 \cdot 8\end{array}$ \\
\hline Total & 223 & $100 \cdot 0$ & 1,021 & $100 \cdot 0$ \\
\hline
\end{tabular}

Previous Admissions

The figures for previous admissions are seen in Table III. Of UHW admissions $68.1 \%$ had had none or one previous admission, compared with $46.3 \%$ of the Whitchurch cohort. Only 10 patients $(4.5 \%)$ at UHW had had more than 10 previous admissions, but $98(9.6 \%)$ of the Whitchurch cohort.

The meaning of these figures is somewhat obscured by the presence of the 'one year rule', which decrees that if patients are readmitted within one year of discharge, then they will return to the bed of the consultant under whose care they were previously. Nonetheless, if readmission rate is a measure of chronicity of illness, then Whitchurch Hospital admits a significantly greater proportion of chronic patients than does the general hospital unit.

TABLE III PREVIOUS ADMISSIONS

\begin{tabular}{|c|c|c|c|c|c|c|}
\hline \multirow{2}{*}{\multicolumn{3}{|c|}{$\begin{array}{c}\text { Number of Previous } \\
\text { Admissions }\end{array}$}} & \multicolumn{2}{|c|}{$\begin{array}{l}\text { UHW } \\
\text { Patients }\end{array}$} & \multicolumn{2}{|c|}{$\begin{array}{l}\text { Whitchurch } \\
\text { Patients }\end{array}$} \\
\hline & & & No. & $\%$ & No. & $\%$ \\
\hline $\begin{array}{l}0 \\
1 \\
2-5 \\
6-10 \\
11-20 \\
>20\end{array}$ & $\begin{array}{l}\ldots \\
\cdots \\
\ldots \\
\ldots \\
\ldots\end{array}$ & $\begin{array}{l}\cdots \\
\cdots \\
\cdots \\
\cdots\end{array}$ & $\begin{array}{r}104 \\
48 \\
48 \\
13 \\
10 \\
0\end{array}$ & $\begin{array}{r}46 \cdot 6 \\
21 \cdot 5 \\
21.5 \\
5.8 \\
4.5 \\
-\end{array}$ & $\begin{array}{r}293 \\
180 \\
289 \\
161 \\
73 \\
25\end{array}$ & $\begin{array}{r}28 \cdot 7 \\
17 \cdot 6 \\
28 \cdot 3 \\
15 \cdot 8 \\
7 \cdot 2 \\
2 \cdot 4\end{array}$ \\
\hline$\overline{\text { Total }}$ & . & . & 223 & $100 \cdot 0$ & 1,021 & $100 \cdot 0$ \\
\hline
\end{tabular}

\section{Diagnosis}

The diagnostic categories of patients in both cohorts are seen in Table IV. In view of the difficulties concerning the classification of depression, both depressive psychosis (ICD 296.2) and depressive neurosis (ICD $300 \cdot 4$ ) have been classified together as 'depression'. It can be seen from the table that relatively more psychotic patients are admitted to the mental hospital, whereas relatively more neurotics are admitted to the general hospital unit. 
TABLE IV

DIAGNOSIS

\begin{tabular}{|c|c|c|c|c|c|}
\hline \multirow{2}{*}{\multicolumn{2}{|c|}{ Diagnosis }} & \multicolumn{2}{|c|}{$\begin{array}{l}\text { UHW } \\
\text { Patients }\end{array}$} & \multicolumn{2}{|c|}{$\begin{array}{l}\text { Whitchurch } \\
\text { Patients }\end{array}$} \\
\hline & & No. & $\%$ & No. & $\%$ \\
\hline $\begin{array}{l}\text { Neurosis } \\
\text { Personality disorde } \\
\text { AJcohol and drugs. } \\
\text { Depreasion } \\
\text { Schizophrenia } \\
\text { Dementia } \\
\text { Other psychoses : } \\
\text { Other .. }\end{array}$ & $\begin{array}{l}\ddot{\operatorname{der}} \\
\cdots \\
\cdots \\
\cdots \\
\cdots\end{array}$ & $\begin{array}{r}32 \\
33 \\
19 \\
74 \\
31 \\
1 \\
17 \\
16\end{array}$ & $\begin{array}{r}14 \cdot 3 \\
14 \cdot 8 \\
8 \cdot 5 \\
33 \cdot 2 \\
13 \cdot 9 \\
0 \cdot 4 \\
7 \cdot 6 \\
7 \cdot 2\end{array}$ & $\begin{array}{r}92 \\
138 \\
67 \\
280 \\
237 \\
54 \\
109 \\
44\end{array}$ & $\begin{array}{r}9 \cdot 0 \\
13 \cdot 5 \\
6 \cdot 6 \\
27 \cdot 4 \\
23 \cdot 2 \\
5 \cdot 3 \\
10 \cdot 7 \\
4 \cdot 3\end{array}$ \\
\hline Total & $\cdots$ & 223 & $100 \cdot 0$ & 1,021 & $100 \cdot 0$ \\
\hline
\end{tabular}

\section{LENGTH OF STAY}

The mean length of stay of those patients discharged within three months was $31 \cdot 3$ days for the UHW cohort (25.8 days for males and 35.0 days for females), and 25.0 days for the Whitchurch cohort (23.4 days for males and 25.9 days for females). Table $\mathrm{V}$ shows that a greater proportion of the patients stay for longer than three months at the general hospital unit than at the mental hospital $(18.6 \%$ as compared with $13.6 \%)$. There are some interesting comparisons to be made between these two groups of 'long-stay' patients.

The age distribution differs markedly between the two hospitals (Table VI). The long-stay patients at Whitchurch are predominantly elderly people, whereas in the UHW group the younger ages predominate.

There are also differences in the distribution of diagnoses. Schizophrenia, depression, dementia, and other psychoses account for $74.2 \%$ of the Whitchurch group but only $51 \cdot 4 \%$ at UHW: neurosis

TABLE V

LENGTH OF STAY

\begin{tabular}{|c|c|c|c|c|c|c|}
\hline \multirow{2}{*}{\multicolumn{3}{|c|}{ Length of Stay (days) }} & \multicolumn{2}{|c|}{$\begin{array}{l}\text { UHW } \\
\text { Admissions }\end{array}$} & \multicolumn{2}{|c|}{$\begin{array}{l}\text { Whitchurch } \\
\text { Admissions }\end{array}$} \\
\hline & & & No. & $\%$ & No. & $\%$ \\
\hline $\begin{array}{r}<7 \\
7-14 \\
15-28 \\
29-42 \\
43-56 \\
57-70 \\
71-90 \\
>90\end{array}$ & $\begin{array}{l}\ldots \\
\cdots \\
\cdots \\
\cdots \\
\cdots \\
\cdots\end{array}$ & 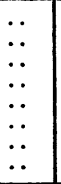 & $\begin{array}{l}22 \\
23 \\
38 \\
35 \\
28 \\
18 \\
16 \\
41\end{array}$ & $\begin{array}{r}10 \cdot 0 \\
10 \cdot 4 \\
17.2 \\
15 \cdot 8 \\
12 \cdot 7 \\
8 \cdot 1 \\
7 \cdot 2 \\
18 \cdot 6\end{array}$ & $\begin{array}{r}217 \\
138 \\
198 \\
129 \\
94 \\
52 \\
36 \\
136\end{array}$ & $\begin{array}{r}21 \cdot 7 \\
13.8 \\
19.8 \\
12.9 \\
9.4 \\
5.2 \\
3.6 \\
13.6 \\
\end{array}$ \\
\hline Total & $\cdots$ & .. & 221 & $100 \cdot 0$ & 1,000 & $100 \cdot 0$ \\
\hline \multicolumn{3}{|c|}{$\begin{array}{l}\text { Mean length of stay, } \\
\text { patients discharged } \\
\text { within three months }\end{array}$} & \multicolumn{2}{|c|}{$31 \cdot 3$ days } & \multicolumn{2}{|c|}{25.0 days } \\
\hline
\end{tabular}

Deaths are excluded from the above figures.
TABLE VI

AGE DISTRIBUTION OF 'LONG-STAY' PATIENTS

\begin{tabular}{|c|c|c|c|c|c|c|}
\hline & & & \multicolumn{2}{|c|}{$\underset{\text { Admissions }}{\text { UHW }}$} & \multicolumn{2}{|c|}{$\begin{array}{l}\text { Whitchurch } \\
\text { Admissions }\end{array}$} \\
\hline \multicolumn{3}{|c|}{ Age (years) } & No. & $\%$ & No. & $\%$ \\
\hline $\begin{array}{l}<20 \\
20-29 \\
30-39 \\
40-49 \\
50-59 \\
60-65 \\
>65\end{array}$ & $\begin{array}{l}\ldots \\
\because \\
\because \\
\because \\
\cdots\end{array}$ & $\begin{array}{l}\because \\
\because \\
\because \\
\because \\
\because \\
.\end{array}$ & $\begin{array}{r}7 \\
10 \\
8 \\
5 \\
7 \\
0 \\
4\end{array}$ & $\begin{array}{c}17 \cdot 1 \\
24 \cdot 4 \\
19 \cdot 5 \\
12 \cdot 2 \\
17 \cdot 1 \\
\overline{9 \cdot 8}\end{array}$ & $\begin{array}{r}5 \\
23 \\
15 \\
22 \\
22 \\
12 \\
37\end{array}$ & $\begin{array}{r}3.7 \\
16.9 \\
11 \cdot 0 \\
16.2 \\
16.2 \\
8.8 \\
27 \cdot 2\end{array}$ \\
\hline$\overline{\text { Total }}$ & .. & $\ldots$ & 41 & $100 \cdot 0$ & 136 & $100 \cdot 0$ \\
\hline
\end{tabular}

and personality disorder account for $34.3 \%$ of the UHW group, but only $20.6 \%$ of patients are in this category at Whitchurch Hospital.

\section{Social Class}

The social class distribution of the two cohorts of patients can be seen in Table VII. Relatively more patients from the higher socio-economic groups are admitted to the general hospital unit than to the mental hospital. This bias is unlikely to arise from emergency admissions, since it is improbable that upper social class patients become ill on Wednesdays, and thus get admitted to the University Hospital, rather than on any other day. The same is true for admissions from other hospitals and domiciliary visits, as these are usually dealt with by the duty firm of the day.

If the social class distribution of patients admitted from outpatients is analysed, this offers some explanation for the bias (Table VIII). Of outpatient admissions to the UHW unit, $29 \cdot 2 \%$ were from social classes I and II, and $10.1 \%$ from classes IV and $\mathrm{V}$. The corresponding figures for outpatient admissions to Whitchurch Hospital were $11.8 \%$ and $23 \cdot 7 \%$ respectively.

TABLE VII

SOCIAL CLASS DISTRIBUTION OF PATIENTS

\begin{tabular}{|c|c|c|c|c|c|}
\hline \multirow{2}{*}{\multicolumn{2}{|c|}{ Social Class }} & \multicolumn{2}{|c|}{$\begin{array}{c}\text { UHW } \\
\text { Admissions }\end{array}$} & \multicolumn{2}{|c|}{$\begin{array}{l}\text { Whitchurch } \\
\text { Admissions }\end{array}$} \\
\hline & & \multirow[b]{2}{*}{$\begin{array}{c}\text { No. } \\
24 \\
42 \\
24 \\
43 \\
16 \\
15 \\
44 \\
15\end{array}$} & \multirow[b]{2}{*}{\begin{tabular}{r}
\multicolumn{1}{c}{$\%$} \\
10.8 \\
18.8 \\
10.8 \\
19.3 \\
7.2 \\
6.7 \\
19.7 \\
6.7
\end{tabular}} & \multirow[b]{2}{*}{$\begin{array}{r}\text { No. } \\
10 \\
66 \\
134 \\
185 \\
124 \\
116 \\
194 \\
192\end{array}$} & \multirow[b]{2}{*}{$\begin{array}{c}\% \\
1.0 \\
6.5 \\
13.1 \\
18.1 \\
12.1 \\
11.4 \\
19.0 \\
18.8\end{array}$} \\
\hline $\begin{array}{ll}\text { II } & . \\
\text { IIInm } & \cdots \\
\text { IIIm } & \cdots \\
\text { IV } & \cdots \\
\text { V Unclassified } \\
\text { Retired } & \ldots\end{array}$ & $\begin{array}{l}. \\
\because \\
\because \\
\because \\
\because \\
\cdots\end{array}$ & & & & \\
\hline Total & . & 223 & $100 \cdot 0$ & 1,021 & $100 \cdot 0$ \\
\hline
\end{tabular}


TABLE VIII

SOCIAL CLASS DISTRIBUTION OF ADMISSIONS VIA OUTPATIENTS

\begin{tabular}{|c|c|c|c|c|c|}
\hline \multirow{2}{*}{\multicolumn{2}{|c|}{ Social Class }} & \multicolumn{2}{|c|}{$\underset{\text { Admissions }}{\text { UHW }}$} & \multicolumn{2}{|c|}{$\begin{array}{l}\text { Whitchurch } \\
\text { Admissions }\end{array}$} \\
\hline & & No. & $\%$ & No. & $\%$ \\
\hline $\begin{array}{lc}\text { II } & . \\
\text { IIIInm } & \ldots \\
\text { IIIm } & . \\
\text { IV } & . \\
\text { V } & 0 \\
\text { Unclassified } \\
\text { Retired } & . .\end{array}$ & 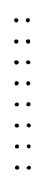 & $\begin{array}{r}8 \\
18 \\
8 \\
26 \\
5 \\
4 \\
13 \\
7\end{array}$ & $\begin{array}{r}9 \cdot 0 \\
20 \cdot 2 \\
9 \cdot 0 \\
29 \cdot 2 \\
5 \cdot 6 \\
4 \cdot 5 \\
14 \cdot 6 \\
7 \cdot 9\end{array}$ & $\begin{array}{r}2 \\
19 \\
18 \\
19 \\
28 \\
14 \\
50 \\
27\end{array}$ & $\begin{array}{l}1 \cdot 1 \\
10 \cdot 7 \\
10 \cdot 2 \\
10 \cdot 7 \\
15 \cdot 8 \\
7 \cdot 9 \\
28 \cdot 2 \\
15 \cdot 3\end{array}$ \\
\hline Total & .. & 89 & $100 \cdot 0$ & 177 & $100 \cdot 0$ \\
\hline
\end{tabular}

\section{Discharge}

As noted earlier, $41(18.6 \%)$ of the UHW patients and $136(13.6 \%)$ of the Whitchurch patients were not discharged within three months. Of those who did leave hospital within this period of time, $48.4 \%$ of UHW patients became outpatients, as did $46.4 \%$ of Whitchurch Hospital patients. Of UHW patients $15.6 \%$ and of Whitchurch patients $16 \cdot 1 \%$ became day patients, either at the Day Hospital at Whitchurch or at the University Hospital.

Ten patients left the UHW unit against medical advice during the first month of its operation. Since then this has happened only rarely. At Whitchurch an average of six patients per month leave against medical advice.

Nineteen of the patients admitted to Whitchurch during the year of the survey died, whereas at UHW two died.

\section{Discussion}

Many of the conclusions of this survey are apparent from the results. Patients admitted to the general hospital unit tend to be younger, of higher social class, neurotic rather than psychotic, and will probably have had fewer previous admissions than will those patients admitted to the mental hospital. They will, however, probably stay in hospital longer.

How significant is all this? The first question to be asked is how much of this difference in the patient populations is due to the fact that the UHW unit is in the main an academic unit? This question can be answered by looking at the characteristics of patients admitted to the Whitchurch Hospital academic unit to see if they resemble the UHW patients rather than the Whitchurch Hospital patients as a whole.
The mean age of patients admitted to the Whitchurch Hospital academic unit was $44 \cdot 3$ years, and the mean length of stay (of those discharged within three months) was 23.4 days. These figures are not significantly different from the figures for all Whitchurch Hospital acute admissions. The Whitchurch academic unit admitted $54 \cdot 2 \%$ of its patients from the emergency assessment clinic and $12.5 \%$ of its patients from outpatient clinics and the waiting list. Again, this is the profile of the Whitchurch cohort rather than that of the general hospital unit. The distribution of diagnoses and the social class distribution of the Whitchurch Hospital academic unit patients were not significantly different from the distributions for all Whitchurch admissions.

It is evident that the differences in characteristics of the two patient populations are not explained by the presence of the prestige associated with an academic unit.

At least part of the differences appears to be due to admissions from outpatients. As stated earlier, the general hospital unit admits significantly more patients from the clinic, and they tend to be of a higher social class. Also, outpatient admissions to Whitchurch contain a higher proportion $(27.9 \%)$ of psychotic patients (schizophrenia and other psychoses) than do outpatient admissions to the UHW unit $(14.7 \%$ of the total clinic admissions). The reverse is true for neurosis $(12.5 \%$ of clinic admissions to Whitchurch as compared with $20 \cdot 1 \%$ to the UHW unit).

There are probably at least two factors involved in this. General practitioners may tend to refer 'better' patients to the clinics with access to beds in the general hospital unit, believing that if they are to be admitted, the environment will be more congenial. Also, some consultants tend not to offer mental hospital admission to the middle class patient, knowing that this will be unacceptable.

Jones and Sidebotham (1962) feel that the district general hospital psychiatric unit 'provides a valuable means of treating some patients, but is unsuitable for the majority'. On the other hand, Silverman $(1961,1968)$ has argued that a unit based on the general hospital is capable of providing a comprehensive psychiatric service. That this is a matter of extreme importance to the future of psychiatry was highlighted by the meeting of the Royal College of Psychiatrists in March 1973. The President of the College posed a number of questions for discussion, and it is relevant to mention two of them here.

'Can it (the DGH unit) provide for every type of psychiatric patient ...?' The view of Jones, quoted above, is that it cannot. There is no evidence from 
this survey that this is true, but there is evidence that it does not, and that a two-tier service has developed in Cardiff.

'How is a two-standard service to be evoided?' Experience in Cardiff has shown that making psychiatrists aware of the problem is important here. The trends described above were known within six months of the opening of the UHW unit, and made known locally; it is therefore of interest to compare the findings for the first six months with those of the second six months (Table IX). The

TABLE IX ADMISSIONS TO UHW

\begin{tabular}{|c|c|c|c|c|}
\hline & \multicolumn{2}{|c|}{1 June-30 Nov. 1972} & \multicolumn{2}{|c|}{1 Dec. $\underset{1973}{1972-31}$ May } \\
\hline & No. & $\%$ & No. & $\%$ \\
\hline $\begin{array}{lll}\text { Total } & \ldots & \ldots\end{array}$ & 113 & $100 \cdot 0$ & 110 & $100 \cdot 0$ \\
\hline $\begin{array}{l}\text { Neurosis } \\
\text { Schizophrenia and } \\
\text { other psychosis } \\
\text { (excl. depression) }\end{array}$ & 19 & $\begin{array}{l}15 \cdot 0 \\
16 \cdot 8\end{array}$ & $\begin{array}{l}15 \\
29\end{array}$ & $\begin{array}{l}13 \cdot 6 \\
26 \cdot 4\end{array}$ \\
\hline $\begin{array}{l}\text { Social classes I and } \\
\text { II } \ldots \\
\text { Social classes IV and }\end{array}$ & 35 & $31 \cdot 0$ & 31 & $28 \cdot 2$ \\
\hline $\begin{array}{llll}\mathbf{v} & \cdots & \cdots\end{array}$ & 14 & $12 \cdot 4$ & 17 & $15 \cdot 5$ \\
\hline $\begin{array}{l}\text { Less than } 20 \text { yr old } \\
\text { More than } 65 \text { yr old }\end{array}$ & $\begin{array}{r}15 \\
5\end{array}$ & $\begin{array}{r}13 \cdot 3 \\
4 \cdot 4\end{array}$ & $\begin{array}{r}14 \\
7\end{array}$ & $\begin{array}{r}12 \cdot 7 \\
6 \cdot 4\end{array}$ \\
\hline $\begin{array}{c}\text { Stay longer than } 90 \\
\text { days } \ldots\end{array}$ & 26 & $23 \cdot 0$ & 15 & $13 \cdot 6$ \\
\hline
\end{tabular}

trend, although not statistically significant, is away from the young, middle class neurotic. In the second half of the year the trend was towards admitting more persons from the lower social classes, and more psychotics; more persons over 65 years were admitted, and fewer patients stayed for more than 90 days at the UHW unit.

The above study has described the development of a trend which has significance for the future of the mental hospital. Early and Magnus (1966) drew attention to the long-term consequences of this type of stratification of services:

"The custodial care of the organically demented, the "hopeless" chronic psychotic, of the subnormal and of the disturbed or criminal psychopath will be the role forced upon the mental hospital ..... if this happens, then the wheel will have turned full circle and the mental hospital will have become what the workhouse was a century ago'.

My thanks are due to Professor K. Rawnsley and Dr. A. C. Brown for advice and encouragement. Thanks are also due to Dr. T. Jenkins for assistance in collection of the data: and to Mr. R. G. Reeves (Admissions and Statutory Officer, Whitchurch Hospital) and his staff, without whose assistance this survey would have been considerably more difficult and much less comprehensive.

\section{REFERENCES}

Brown, A. C. (1967). In-patient census, Whitchurch Hospital (unpublished).

Early, D. F. and Magnus, R. V. (1966). Population trends in a mental hospital. Brit. J. Psychiat., 112, 595.

Jones, K. and Sidebotham, R. (1962). Mental Hospitals at Work. Routledge and Kegan Paul, London.

General Register Office (1968). A Glossary of Mental Disorders. Based on the International Statistical Classification of Diseases, 8th revision, 1965. Studies on Medical and Population Subjects No. 22. HMSO, London.

(1971). Classification of Occupations 1970. HMSO, London.

Royal College of Psychiatrists (1973). Providing a comprehensive district psychiatric service for the adult mentally ill. Brit. J. Psychiat., Suppl., June 1973.

SiLVERMAN, M. (1961). A comprehensive department of psychological medicine. Brit. med. J., 2, 698.

- (1968). Further studies on a comprehensive department of psychological medicine. Brit. J. Psychiat., 114, 493. 